\title{
Paideusis
}

\section{An Unabashedly Non-Arm's-Length Account of My Lifelong Affair with Philosophy}

Dwight Boyd

Volume 19, Number 2, 2010

URI: https://id.erudit.org/iderudit/1071919ar

DOI: https://doi.org/10.7202/1071919ar

See table of contents

Publisher(s)

Canadian Philosophy of Education Society

ISSN

0838-4517 (print)

1916-0348 (digital)

Explore this journal

Cite this document

Boyd, D. (2010). An Unabashedly Non-Arm's-Length Account of My Lifelong Affair with Philosophy. Paideusis, 19(2), 32-41.

https://doi.org/10.7202/1071919ar viewed online.

https://apropos.erudit.org/en/users/policy-on-use/ 


\title{
An Unabashedly Non-Arm's-Length Account of My Lifelong Affair with Philosophy
}

\author{
DWIGHT BOYD \\ Ontario Institute for Studies in Education, University of Toronto
}

\section{Very Early Impulses}

My life-long favourable disposition toward philosophy started very early, although unknowingly to me at the time. It sneaked up on me very gradually, perhaps starting as early as the age of nine and certainly by early adolescence. It was probably prompted by where I spent my childhood and teen years. I grew up on a family farm in southeastern Kansas, the kind of farm on which work was the default position for everyone, whatever your age. So, by nine, I was deemed old enough to graduate from garden work with my mother to "going to the field" on a tractor by myself for many hours at a time. By early adolescence this meant full days of 12 to 14 hours. Due to childhood asthma, my assigned task for most of the summer was cultivating the corn and beans with an old Case tractor. This required sitting on an iron seat with no back, trying to "man"-handle a tractor with no power steering and bad brakes, and doing so with unwavering concentration to avoid moving more than two inches to the right or left and thus plowing up the tiny plants I was supposed to be nurturing. Now, part of the point of noting these details is to emphasize that this was an inherently lonely way to spend much of my early life. I was forced by necessity to be my own company for these long hours. But the main point here is what can be done with that company. Another detail thus needs to be added: all of this went on at the often break-neck speed of one mile an hour. So it must be said that this work was also inherently boring. Daydreaming was one way of dealing with this boredom, but at that age and on a Kansas farm, the content of this itself can be equally boring. I soon discovered that active thinking was much less boring-and much less likely to result in the fence at the end of the row suffering serious injury because a tractor had failed to turn soon enough. Thus, if philosophy involves focused thought, and, in particular, thinking about thinking, I suspect it was cultivated into my bones at a very early age.

To be clear, none of this is meant to suggest that I was some sort of philosophical prodigy, something like one of the main characters in an early Mathew Lipman philosophy-for-children novel. Or, that I even knew what philosophy was. In fact, those involved in a Kansas farm life in the late forties and early to late fifties seemed singularly unaware of the existence of philosophy. (However, having recently found and reread two letters that my father wrote me, one when I graduated from high school and the other when I decided to apply for Conscientious Objector status to the Vietnam War, I must add that I think my father was a natural born philosopher. Almost always, he could see at least two sides to any question.) Thus, exposure to the real stuff came relatively late, not until I went to university. In fact, I think it fair to say that my early schooling did not support this kind of thinking, and in many ways militated against it. When one's first three years of school are located in a three-room schoolhouse with one teacher, no classmates, no indoor plumbing, and only five students in year three (and one of those was an older brother), the curriculum is pretty basic. Still, since I almost always

(C) Copyright 2010. The author, Dwight Boyd, assigns to Paideusis the right of first publication and educational and non-profit institutions a non-exclusive license to use this document for personal use and in courses of instruction provided that the article is used in full and this copyright statement is reproduced. Any other usage is probibited without the express permission of the author. 
finished my assigned lessons by noon, I did have hours every day to listen to the teacher's lessons to the "big kids", to play (on my own, of course), and, perchance, to think. My experience was nudged toward the more normal from grade four until high school graduation by the closure of the country school and our move to the local "town school." Still, with only 19 classmates and only 120 in the whole school, the curriculum was far from rich. For example, no foreign languages were taught; English was mostly grammar; and only a little science and mathematics was offered. Football was king. Any students inclined in the direction of thinking about thinking were left to their own devices-if not outright discouraged for being seen as having their head in the clouds. However, I may have received a subtle-and certainly unintentional—nudge toward my eventual interest in philosophy of education from many of my classroom experiences in these early years. Although I honestly do not think I was an arrogant young person (much closer to shy, timid, and introverted), I do remember often wondering to myself why the teacher could not seem to understand my classmates' questions - and thinking that I could do it better.

\section{Early Encounters and Influences}

The subjects that most attracted me in high school were mathematics, chemistry, and physics. They were exciting because they offered new ideas and new ways of thinking about the world. (This likely explains to a large extent why to this day I remember vividly how engrossed I became in the only two substantive research papers I was asked to write in four years of high school. Free to choose, I wrote one on the historical development of the periodic table of elements and the other on bubbles.) It also helped that I was good at them. For both of these reasons, and with very little prudential or strategic consideration, I thought I would concentrate on these subjects when I enrolled in the University of Kansas for a B.A. in the fall of 1963. Although I took seriously the need to learn how to write and to learn a foreign language (German), the focus on science dominated in my first two years.

One significant exception to this focus, however, undoubtedly influenced my subsequent path: I also took a philosophy course in ethics in my second year. My professor was David Jones, a recent doctoral graduate of the Harvard University's Department of Philosophy. It not only exposed me for the first time to some of the "greats" in the Western tradition of moral philosophy, but also introduced me to the contemporary thinking of some philosophers that I would subsequently have the opportunity to study with - in particular, Roderick Firth and John Rawls. What really excited me about this course was the way it seemed in places to speak directly to my life, especially to patterns of thinking that I held, but that seemed at the same time somehow constraining, if not downright morally debilitating. One example was the problematic forms of relativistic thinking. Another, even more personally significant, was my adolescent tendency to be attracted to psychological egoism. Through this course, I learned that this seemingly unassailable belief could be shown — through clear, systematic analysis — to be naïve at best, and arguably flat-out wrong. To this day, I can still remember being stunned by how Jones used something from the eighteenth-century philosopher Bishop Butler to escape what I later referred to in print as the "quicksand" of an unexamined belief in the truth of psychological egoism as an allencompassing explanatory framework of human motivation. I now suspect that this personal experience foretold—and perhaps causally shaped - much of the way I have approached philosophy and philosophy of education in all of my subsequent philosophical studies and professional research and writing. Without a doubt, as I will explain later, it planted the seed of my appreciation of the significance of Lawrence Kohlberg's work in the psychology of moral development that shaped a good part of both my graduate work and much of my early career.

My budding scientific career did not survive beyond my second year (although to this day, I remain on the lookout for an issue of magazines like Scientific American with articles that I think I might understand, especially on topics pertaining to cosmology and time). Back then, I was not (and still am not) a big fan of large, bureaucratically run institutions, but just occasionally they accidentally do some 
good for some individuals. I was required by my university to formally "declare" a major before I would be allowed to register for my third year. I knew that science and mathematics no longer felt right. I also had learned that, despite getting almost all "A's" in these areas, I was not as good in these subjects as some of my classmates—or, at least, their "A's" seemed to come more easily than mine. I also had come to realize that I had many questions that no science or mathematics could answerquestions of meaning, conceptual connection, and justification, especially, moral and political justification. This latter insight came not from any class, but from long, vehemently-argued "BS" sessions with my two closest friends and classmates in the student-run Scholarship Hall where we resided. (Today, one is a renowned physical chemist at Brown University and the other, a very successful psychiatrist in New York.) But what to do given these realizations? My approach to answering this burning question of a major was hardly philosophical, but more like what one might learn on a farm. In short, I sat down with the University of Kansas catalogue of course offerings and went through it page by page, reading the course titles and brief descriptions and asking myself, "Does this grab me?" To be honest, the answer was overwhelmingly negative for most entries. But, there were some-and almost all of these were found (surprise, surprise) in the Department of Philosophy. Ergo, young Mr. Boyd was duly registered as a philosopher-to-be.

On the whole, I found the philosophical world to be a comfortable one, and courses in the philosophy department took up most of my schedule for my two final years. There were, however, notable exceptions: for example, my exposure in a second-year linguistics course to the Benjamin Lee Whorf hypothesis concerning how our way of understanding of the world is constrained so much by one's first language. That led to my subsequent third-year decision to "test" it via a very intensive year of Chinese language study. In addition, my one exposure to psychology, although not through a course, proved to be a subsequently powerful, almost prophetic, influence. For one summer month, I was hired by Jones to read and summarize in writing all of the very extensive entries in the bibliography at the end of the chapter on "The Acquisition of Morality" in Roger Brown's widely used textbook Social Psychology. About the only entry that seemed to me-and to Jones-philosophically informed and interesting was a paper by a young psychologist at Chicago by the name of Lawrence Kohlberg. I tried to find another paper of his listed in the bibliography of the one paper of his that I did find, but couldn't locate it. I followed Jones' wise and surprising suggestion of 'Well, why don't you just write him?", only to learn from his secretary that Professor Kohlberg was in Taiwan doing research and would thus not be able to answer my inquiry. I distinctly remember thinking "Too bad. That guy's integration of psychology and philosophy sounds very interesting ... but I guess that's the end of that." In fact, however, this experience would very soon prove to be my entry card into an approach to philosophy that has been one of my main academic interests and hallmark of much of my past-and current-research and publication.

Although I performed very well in the philosophy courses, I must admit that I found most of them boring and "dry" in much of their content and almost all of their pedagogy. "Dry" in this case should be understood as the opposite of what I experienced in Jones' ethics course-that is, what I learned in these other courses seemed so far from connecting with my life that they provided more intellectual exercise than personally insightful ways of thinking about my thinking. Not to put too fine of a gloss on it, by the end of my third-year I was burnt out, bone tired of sitting through these courses (although I enjoyed writing the papers). My interest in philosophy, and likely my career, was saved by a creative Associate Dean of Arts and Sciences, someone I did not even know at the time. Apparently understanding the danger of burnout for some students, Dean Bell initiated a special "Senior Independent Study Program," and offered, on the basis of our academic record to date, thirteen fourthyear students the option to sign up for it. There were just two requirements beyond carrying a full course load in terms of hours: (1) we could not register in any existing regular course offering; and (2) we had to design our own individual reading courses in whatever areas we desired and find professors to supervise them. In this context, I flourished again, even in a course in which I required myself to 
read and write about Kant's ethical works, supervised by the then chair of the department, Richard DeGeorge.

My personal contact with DeGeorge proved to be very helpful, not so much in terms of content, but in a surprising way that changed my philosophical path radically. On the basis of my record, he encouraged me to apply to philosophy departments in several major universities-namely, Chicago, Northwestern, Princeton, Yale, and Harvard (admittedly a long stretch from cultivating corn in Kansas). To my huge disappointment and DeGeorge's expressed surprise, I was accepted with funding only by Northwestern University. I also received a letter from the Harvard Graduate School of Education (HGSE) congratulating me for being nominated for a fellowship to study philosophy of education. This letter puzzled me considerably, as I had not applied to HGSE—or even considered applying there, having no idea that this program existed...or, to confess, even what exactly philosophy of education was. When I took this news to DeGeorge, and asked him what he thought it meant, he revealed the role he had taken. He told me that Israel Scheffler at HGSE had written to a number of chairs of philosophy departments around the country asking for recommendations of names of students deemed strong in philosophy, as he had an agenda (something I learned later) to beef up the philosophical nature of the field of philosophy of education by attracting high-calibre students. When I eventually learned that HGSE would also spring for a major fellowship, I began to seriously consider accepting, because I was really worried about the depth of my interest in "pure" philosophy. So I asked my early mentor, David Jones, for his advice. His answer was that I should take the offer from Harvard because, although it was a "back door," it was "still a way in." So I ended up, almost by accident, in an academic environment quite different from any I could have imagined when I started my philosophical journey.

\section{Major Persons of Influence}

My years of residence study at Harvard, 1967 to 1972, (minus two years leave from 1968 to 1970 , during which time I worked at the Massachusetts General Hospital as a conscientious objector to the war in Vietnam) were heady years-extremely intense and rewarding. I was there when some prominent scholars were making major splashes on the academic scene and, thus, had the opportunity to work with them. These included Michael Walzer, Roderick Firth, Hilary Putnam, Israel Scheffler, David Purpel, Lawrence Kohlberg, and John Rawls. (At the time, I don't think it even crossed my mind that these were all men, but it certainly does now. Indeed, I have serious concerns about how this fact must have shaped my thinking and approach to philosophy, concerns that were much later appropriately brought to my attention by feminist scholars such as Jane Roland Martin, Nel Noddings, Patricia Williams, and Iris Marion Young.) In particular, Scheffler was in the process of writing some of his most notable books and his lectures were often pieces for those books. Rawls was approximately three-quarters through writing $A$ Theory of Justice (1971), and his lectures in a course on political philosophy were almost exclusively from his work-in-progress. By the time I returned to university in 1970 , the work was completed, and when I sat in on his course again, I was able to witness this progress. Kohlberg was entering the most productive years of his career in terms of influence on the field of developmental psychology, his ability to get major funds to support his research, and the involvement of his graduate students in the on-going, "boot-strapping" revision and refinement of his theory of moral development.

Let me make concrete and personal the impact this opportunity had on me. In my very first term of study at Harvard (Fall 1967), I had the opportunity to take courses from both Kohlberg and Rawls. In my registration package, I discovered a special sheet identifying a new course in moral development taught by an "L. Kohlberg," newly arrived at HGSE. I wondered if it was the same guy that I had stumbled on in my work for Jones, and had subsequently tried unsuccessfully to contact by letter. So I went to see him. It was. And he let me into the course despite the fact that I had not one course in my 
B.A. in psychology. (I suspect he admitted me on the strength of my recounting my summer research with Jones and my early interest in contacting him.) Then, on the basis of having read in Jones' course a very early paper by Rawls entitled "Justice as Fairness," I also jumped at the chance to register in his course on political philosophy and to join the graduate student discussion section led by him. To make this impact really concrete, I remember on several occasions suggesting to Kohlberg that a more adequate way of thinking about what his "stage 6" was all about might be pursued by utilizing some of the ideas in this new work of Rawls... and then trotting off to Rawls' discussion section and suggesting to him that he was making empirical assumptions in his argument that carried significant weight, and it seemed to me that this guy Kohlberg had findings directly relevant to the soundness of these assumptions. (For those readers who know their respective works, it may be quite apparent that Kohlberg took my suggestion seriously; Rawls, less so, preferring to articulate his own account of moral development that he seemed to think better fit with his concern for "stability" in his ideal just society.)

While engaged in this graduate study, I thought of my work as being located somehow inbetween that of Scheffler, Rawls, and Kohlberg. I still do, in part. Certainly, these three had the most lasting influence on me. From Scheffler, I learned how to think more analytically about education, especially how language can be misused and how it should always be carefully examined. He also introduced me to pragmatism in a way that made the major figures in pragmatism come alive, and in a way that helped me immensely in understanding Kohlberg's deep dependence on Dewey. He also introduced me to the British philosophers of education, particularly Richard Peters, inviting him on several occasions to visit Harvard, give lectures, and talk with the graduate students in philosophy of education. Rawls had a huge influence on me in terms of how I thought about normative questions. His lectures on ethics (published many years later as Lectures on the History of Ethics) were always so systematic, clear, and considerate of those who had gone before him. In particular, as a mode of entering philosophical discussions, I have always tried (though have never been even close to his success in this) to follow his humbling claim that whenever he found something that he thought obviously wrong or misguided in one of the "greats," he would refuse to believe this assessment until he had understood from inside the author's framework why it likely seemed correct from his/her perspective. In addition, I found in Rawls' political philosophy a satisfying account of why the social contract tradition was so attractive to me, an attraction that continued and surfaced often with explicit Rawlsian flavour in my own writing for most of my career.

Finally, although I was a philosophy student, Kohlberg probably had the deepest influence on me. Some of this influence was certainly academic. In particular, I gained from him a deep appreciation of how philosophy and psychology can, and should, complement each other in the study of some kinds of questions. I have kept this appreciation alive throughout my career. While it appears in many of my papers, the earliest example can be found in the topic for my doctoral dissertation. Here, the emphasis was on the justification, development, teaching, and evaluation of a course in ethics for first- and second-year university students. It focused on countering the problematic meta-thinking about moral commitments that so plagued me before the course I took with Jones-what I came to call the "problem of sophomoritis". I have also considered moral education to be one of my central areas of academic research and writing, and this certainly derived from Kohlberg's influence. It was primarily through his urging that I became very active in the Association for Moral Education (including 19861989 as Vice President, and then 1989-1992 as President) and served as the Associate Editor of the Journal of Moral Education where I was responsible for all submissions from North America from 1981 to 1996.

These academic influences have certainly loomed large in shaping my career, but it may be the personal influence that is even more important. Kohlberg had a massive intellect and interest in ideasperhaps one of the few geniuses with whom I have ever had the privilege of having close contact. At the same time, I suspect as a result of his formal training in psychoanalysis, he had the capacity to listen to others' ideas-even those of his graduate students, and even when they raised critical questions about his own theory - as if those who espoused them were true equals. When, in the words of one of 
my classmates, the usual mode of discussion at Harvard seemed to be something like "screwing into each other's foreheads", being consistently the partner in something radically different was truly inspiring. This experience, both in my Harvard years and for the many years until Kohlberg's death, provided me a model that I sought to emulate through my interaction with ideas and those who advanced them, especially my students. It is also likely causally linked to the fact that throughout my career I have found supervision of masters and doctoral students' thesis writing to be at the top of those things that have made my work both pleasurable and rewarding.

\section{Workplace Factors}

Of course, the fact about graduate students having been so central to my activities in philosophy of education likely stems, in part, from the other fact that I taught only graduate students all of my years at the Ontario Institute for Studies in Education (OISE) of the University of Toronto (UT). Like my experience in going to Harvard, I started my career at OISE without knowing anything about the place. Actually, I wasn't even looking for a job. In fact, I was not even sure I wanted to remain in academia. (Studying with the likes of Scheffler, Rawls, and Kohlberg can be quite daunting for a Kansas farm boy, as it was very clear to me that I could never be as insightful or productive as they were.) In 1975, I was finishing my dissertation under the joint supervision of Scheffler and Kohlberg while a marginal "Visiting Scholar" at the University of Washington. While on a trip back to Cambridge to show Kohlberg my latest draft, I was approached by someone in the Department of History and Philosophy of Education at OISE to see if I would like to apply for a position they had open. On considerable urging from Kohlberg, I stopped off in Toronto on my way back to Seattle, interviewed for the position, and two weeks later had it. Thinking that I might go just for one year to test the waters, I stayed for thirty-three years (retiring in 2008).

Although academics often badmouth how their home institutions are run, and I am no exception here, I must say that on the whole OISE was remarkably good to me in offering conditions favourable to my work as a philosopher of education. Having good colleagues with a wide range of scholarly interests was an essential part of these conditions. It now literally astounds me to remember that when I arrived at OISE — and for many years of my early career - the department consisted of six philosophers of education and six historians of education-all devoted to graduate teaching only. It also saddens me to see these numbers dwindle today to three and four, respectively, and with most of these professors split between graduate teaching and teacher preparation teaching. (Considerably more disturbing is the fact that, as I write, our doctoral programs are under serious threat of closure due solely to the fact that we are deemed not to have sufficient faculty to staff them.) In my last few years at OISE, I volunteered to teach one of our required courses to free up new faculty to develop offerings in their own areas of specialization. Prior to that, I had had the luxury of the freedom to design and teach only graduate courses related to my research interests. Moreover, these classes were always relatively small-from four to twelve students. A particularly good example of how this freedom was a benefit to me occurred when I accepted the invitation from the Philosophy of Education Society in 1996 to be the next year's President. I immediately canceled a scheduled course and substituted a special "Research Seminar" that would enable me to focus on developing the ideas for my Presidential Address. In fact, I told the five students who enrolled that this was the reason for the course, outlined the general question on which I wanted to work, and invited them to go along for the ride if they were interested. They were, and did. The result was one of the best educational experiences of my career. It was then made even better when we decided we would like to continue the experience the next term, and I again had the freedom simply to continue to substitute this course for one of my regular offerings.

Two other institutional conditions contributed significantly to my largely positive experience at OISE. First, until OISE was officially merged in 1996 with the University's Faculty of Education (FEUT), it was relatively autonomous. Until that time, OISE focused exclusively on graduate education 
and research, whereas FEUT was responsible for all teacher preparation. Although our degrees were always University of Toronto degrees, we operated administratively with considerable independence. Moreover, OISE then was also run quite democratically. At the Institute level, if faculty felt that a senior administer was not doing a proper job, we could and did pass votes of "no confidence." Almost always, a resignation ensued. In my Department of History and Philosophy, with the exception of confidential matters concerning existing or new students, all decisions were made on a "one-person, one-vote" basis at regular monthly meetings that were open to all members of the department-faculty, students, and staff. This made for long, and often raucous, meetings, but it did contribute significantly to my positive feelings about my academic home because I had a sense of having some genuine say in how it was run. A second positive structurally-related condition was that OISE was then almost entirely financially autonomous: funding came directly from provincial ministries and was not filtered through the huge University of Toronto bureaucracy (UT being the fifth largest university in North America). At the time of the proposed merger, the University's own external consultants pointed explicitly to this fact as contributing significantly to OISE's institutional success relative to many other schools of education that were buried, and often neglected, within their home university's larger interests.

After the merger, both conditions were radically altered. Administration had to be conducted in accordance with the UT's tradition of almost entirely top-down decision making, with deans and chairs having almost all of the say, and faculty and students very little. One example will illustrate how my experience changed significantly. At the time of the merger, a joint OISE/FEUT committee was struck to determine the most appropriate departmental structure of the new, integrated institution. After long and detailed discussions, this committee recommended to the Provost that the existing nine departments in OISE would be the best arrangement academically. Despite this and offering no reasons other than he "liked large departments," he ordered that departments be merged. The result was that History and Philosophy lost its autonomy and became a part of a larger Department of Theory and Policy Studies in Education, linked structurally with two other non-disciplined based programsnamely, Higher Education and Educational Administration. This made no sense on academic grounds. However, our worst fears of losing institutional recognition of the academic uniqueness of both history and philosophy did not materialize in any significant way (at least until the current threat noted above) because the chairs of the new department have recognized that significance and have run the department accordingly as a "federated" entity.

On a more personal, but also on an institutional level, both periods seemed to require of me significant administrative duties. When History and Philosophy was a free-standing department, someone always had to volunteer to be Chair of the whole department. In the pre-merger period, the power of this position was mostly limited to that of persuasion, often akin to herding cats. Moreover, someone had to represent the often-different academic concerns of both history and philosophy in the roles of "program co-coordinators." After the merger, the latter roles continued, but with even greater responsibilities in the face of representing these concerns to colleagues not grounded in any one discipline and considerably more practice-based. As a result, I deemed it an obligation to fill these roles, both chair and program coordinator, for over half of my career. Though I do not harbour serious regrets, I also do not doubt that my curriculum vitae now would look considerably different had so much of my time and energy not been devoted to serving in these administrative roles.

\section{Focus and Changes in My Work}

Even a cursory inspection of my curriculum vitae would reveal that my academic focus has been almost entirely on problems in moral and political philosophy as manifested in educational contexts. For approximately the first half of my career, the emphasis was clearly more in the moral arena, with, as I have already noted, much of the educational context being that of moral education. For the rest, political concerns became much more salient to how I thought about all education, especially its moral 
aspects, and particularly as reflected in problems of oppression such as racism and sexism. This change came gradually, and largely as a result of inviting some of my women graduate students to teach courses with me on different occasions over several years (notably, Maureen Ford, Katherine Pepper-Smith, and Barbara Applebaum). Although gradual, this change had a huge impact on me personally and can clearly be seen in my publications - even in their titles.

Underlying what might seem simply as a change in focus or interest, there is a more substantive change in how I understood social interaction—and, in particular, players in that interaction, especially myself. My early work was clearly, if also largely unselfconsciously, grounded in and limited by the liberal tradition. More precisely, it was limited by a particular strand within that tradition that would probably be recognized by most as social-contractarian in essential aspects, although also clearly shaped by Rawls' particular development of social contract theory. One good example in my publications would be my 1980 paper "The Rawls Connection." Here, I sought to work out in some depth my intuition that Kohlberg's use of Rawls to illustrate his conception of the end point of his understanding of moral development was sound in terms of some basic shared assumptions about the nature of justice. (Recall my academic shuttle-diplomacy between the two in my first year at Harvard.) Although they expressed it in different ways due to the different scopes of their theories, central to this analysis was the way that both depended on a particular view of individuals and their interactions, a claim which Rawls seemed to agree with in a personal, hand-written letter in response to his reading this paper prior to its publication. In essence, this view understands the social entity identified as an "individual" as ontologically unique, symmetrically positioned with respect to others, potentially agentic through intentional rationality, in principle capable of transcending any existing social contingency for the purpose of altering it in some desired direction, and obligated to respect all others as equal placeholders in social interaction. Given these assumptions, justice is then seen by both theorists, not as written into the fabric of the universe and there to be "discovered," but, rather, the emergent, "constructivist" outcome of procedures of inter-subjective moral judgment. Though a severely compressed account of a very complex view, the point here is that it is one that I was working with in this and in several other publications such as the 1989 paper "Moral Education, Objectively Speaking." It is also one that I am somewhat loath to give up entirely.

However, it is exactly what I also began to move away from—or, at least, complicate and qualify as limited-in my more recent work. ${ }^{1}$ What changed, to put it simply, is that I came to understand that these problems are in large part located not in the interaction of individuals as conceived by liberalism-even in a theory as complex and systematic as Rawls'-but in the systemic, structural relationships between social groups that are defined in terms of each other (as in "black/white" and "masculine/feminine"), one dominant and the other oppressed (though I hasten to add that this is a rather gross simplification). It also helped me understand, and to begin to work with, my own social location in these relationships - and, thus, complicity in something that simply cannot be seen adequately from a liberal point of view. In "The Legacies of Liberalism and Oppressive Relations: Facing a Dilemma for the Subject of Moral Education," I tried to address the question of what the subjectivity of members of such groups would look like, specifically in contrast to the picture that offered by liberalism, and why it is so important for moral education to face up to this difference.

\footnotetext{
${ }^{1}$ Examples of the direction of this change are to be found in a number of publications, such as the 1996 paper "A Question of Adequate Aims," my Philosophy of Education Society Presidential Address in 1997, "The Place of Locating Oneself(ves)/Myself(ves) in Doing Philosophy of Education," and the 2004 paper "The Virtues of Educating for Justice." But it is most explicitly reflected in the title and content of my 2003 Kohlberg Memorial Lecture for the Association for Moral Education, "The Legacies of Liberalism and Oppressive Relations: Facing a Dilemma for the Subject of Moral Education." In each of these papers, I acknowledge my huge debt to Iris Marion Young for helping me to see the limits of the liberal view in the face of such pernicious and persisting problems of oppression such as racism, sexism, and classism.
} 
What has not changed, however, is my appreciation of the legitimacy and need to seek points of integration between philosophy and psychology, especially in an educational context. Although I have approached this integration usually from the philosophical side in most of my work, I have on occasion dirtied my hands with data and lived to write about it. However, at the end of my career and in my retirement so far, I have finally had the opportunity to approach the integration from the other side as well. Specifically, I am collaborating with Mary Lou Arnold, a developmental psychologist at OISE, on a large-scale, interdisciplinary study of teachers' and adolescents' awareness and understanding of the social justice problems of racism, sexism, and classism, funded by the Social Sciences and Humanities Research Council of Canada. (It has not escaped our attention that I was one of Kohlberg's first students at Harvard, and Mary Lou was one of his last.) To this empirical study, I have been able to bring the more political orientation of my later years, in particular, to frame some of our questions from the perspective of the contrast between liberalism and a Young-ian conceptual understanding of oppression.

\section{Some Brief Contextual Observations}

A final observation might put some of these personal reflections in the larger context of work in philosophy of education in general. Although I have now been active in this field for 35 years, I have never been very good at trying to synthesize broad directions within it. However, I do feel somewhat safe in making three points. First, I think it is quite evident that work in this field, as represented in the major journals and in the Yearbook of the Philosophy of Education Society, is now much more diverse than when I started. Then, most of what I saw seemed dominated by conceptual analysis (just think of all of those papers on the concept of "indoctrination"). Now that approach is at best one of many, revealing itself more often than not as a "tool" for certain kinds of moves in substantive arguments in work by people of my generation. Second, I also think it is quite evident that most work in philosophy of education today, and for the last 10 to 15 years, is far more sensitive to political dimensions than it was when I started. Although some colleagues might resist this, or would at least want to word it differently, most now recognize that no conception of education can ever be politically neutral, and that there are philosophical implications of this recognition. In this sense, I think the trajectory of changes in my work reflects this broader change in the field. A third observation concerns more what I have not seen in the field at any time. What seems to be largely missing is work that shares, or perhaps even accepts, my belief that philosophy of education and psychology should be seen in a more integrated fashion and that work that fails to take this seriously is, at least on some kinds of questions, unduly impoverished. If philosophy of education is to survive, and thrive, it is my fervent hope that more of my colleagues would take this stance in their work.

\section{References}

Boyd, Dwight. "Moral Education, Objectively Speaking." Ed. James Giarelli. Philosophy of Education 1988. Urbana, IL: Philosophy of Education Society, 1989. 83-100.

Boyd, Dwight. "A Question of Adequate Aims.” Journal of Moral Education 25.1 (1996): 21-29.

Boyd, Dwight. "The Place of Locating Oneself(ves)/Myself(ves) in Doing Philosophy of Education." Ed. Susan Laird. Pbilosophy of Education 1997. Urbana, IL: Philosophy of Education Society, 1998. 1-19. Presidential Address.

Boyd, Dwight. "The Virtues of Educating for Justice in a Diverse Society.” Eds. L. F. Groenendijk and J. W. Steutel. Analytisch Filosoferen over Opvoeding en Onderwijs: Liber Amicurum voor Ben Spiecker 
(Analytic Philosophizing about Upbringing and School Education: Festschrift for Ben Spiecker). Amsterdam: B.V. Uitgeverij SWP, 2004. 139-151.

Boyd, Dwight. "The Virtues of Educating for Justice." 2004.

Boyd, Dwight. "The Legacies of Liberalism and Oppressive Relations: Facing a Dilemma for the Subject of Moral Education." Journal of Moral Education 33.1 (2004): 3-22.

Rawls, John. Lectures on the History of Ethics. Ed. Barbara Herman. Harvard University Press, 2000.

\section{Works That Have Significantly Influenced My Thinking}

Goldberg, David Theo. Racist Culture. Oxford: Blackwell, 1993.

Green, Thomas F. The Activities of Teaching. New York: McGraw-Hill, 1971.

Kohlberg, Lawrence. Essays on Moral Development. Volume One. The Philosophy of Moral Development: Moral Stages and the Idea of Justice. San Francisco: Harper and Row, 1981.

Kohlberg, Lawrence. The Psychology of Moral Development: The Nature and Validity of Moral Stages. Volume Two. San Francisco: Harper and Row, 1984.

Mills, Charles. "Non-Cartesian Sums: Philosophy and the African-American Experience." Teaching Philosophy 17.3 (1994): 223-243.

Mills, Charles. The Racial Contract. Ithaca, NY: Cornell University Press, 1997.

Martin, Jane Roland. "Needed: A New Paradigm for Liberal Education." Philosophy and Education. Eightieth Yearbook of the National Society for the Study of Education, Part 1. Ed. Jonas Soltis. Chicago: National Society for the Study of Education, 1981.

Martin, Jane Roland. “The Ideal of the Educated Person.” Educational Theory 31.2 (1981): 97-109.

Peters, Richard S. Ethics and Education. London: Allen and Unwin, 1968.

Rawls, John. A Theory of Justice. Cambridge, MA: Harvard University Press, 1971.

Rawls, John. Political Liberalism. New York: Columbia University Press, 1993.

Rousseau, Jean Jacques. The Social Contract and Discourses. Trans. G.D.H. Cole. New York: E.P. Dutton and Company, Inc., 1950.

Scheffler, Israel. The Language of Education. Springfield, IL: Charles C. Thomas, 1960.

Williams, Patricia. The Alchemy of Race and Rights: Diary of a Law Professor. Cambridge, MA: Harvard University Press, 1991.

Young, Iris Marion. Justice and the Politics of Difference. Princeton, NJ: Princeton University Press, 1990. 